Jurnal Ekonomi, Bisnis dan Akuntansi (JEBA) Volume 22 No 3 Tahun 2020

\title{
FAKTOR-FAKTOR YANG MEMPENGARUHI PERENCANAAN PAJAK PADA PERUSAHAAN- PERUSAHAAN DALAM INDEKS SAHAM SYARIAH INDONESIA (ISSI) YANG TERDAFTAR DI BURSA EFEK INDONESIA
}

\author{
Sasongko Adi Priyanto1*, Oman Rusmana1, Abdul Aziz Ahmad1 \\ ${ }^{1}$ Program Pascasarjana Magister Akuntansi, Fakultas Ekonomi dan Bisnis, Universitas Jenderal Soedirman, \\ Indonesia \\ *Email corresponding: sasongko.priyantoadi@gmail.com
}

\begin{abstract}
Abstrak
Tujuan penelitian ini adalah untuk menguji pengaruh profitabilitas, leverage, ukuran perusahaan dan capital intensity terhadap perencanaan pajak. Populasi penelitian ini adalah seluruh perusahaan dalam Indeks Saham Syariah Indonesia (ISSI) yang Terdaftar di Bursa Efek Indonesia. Sampel penelitian ini diperoleh dengan menggunakan metode purposive sampling, dimana hanya 202 perusahaan Indeks Saham Syariah Indonesia (ISSI) yang Terdaftar di Bursa Efek Indonesia yang memenuhi semua kriteria yang digunakan sebagai sampel penelitian. Sumber data pada penelitian ini diperoleh dari website Bursa Efek Indonesia. Penelitian ini menggunakan model regresi berganda untuk menguji pengaruh masing-masing variabel terhadap perencanaan pajak. Berdasarkan hasil penelitian menunjukakn bahwa profitabilitas tidak terhadap perencanaan pajak. Leverage berpengaruh positif terhadap perencanaan pajak. Ukuran perusahaan berpengaruh negatif terhadap perencanaan pajak. Capital intensity berpengaruh positif terhadap perencanaan pajak.
\end{abstract}

Kata Kunci: profitabilitas, leverage, ukuran perusahaan, capital intensity, perencanaan pajak

\begin{abstract}
The purpose of this study was to examine the effect of profitability, leverage, company size and capital intensity on tax planning. The population of this research are all companies in the Indonesian Sharia Stock Index (ISSI) which are listed on the Indonesia Stock Exchange. The sample of this study was obtained using the purposive sampling method, where only 202 Indonesian Sharia Stock Index companies (ISSI) registered on the Indonesia Stock Exchange met all the criteria used as research samples. Sources of data in this study were obtained from the Indonesia Stock Exchange website. This study uses multiple regression models to examine the effect of each variable on tax planning. Based on the results of the study indicate that profitability is not to tax planning. Leverage has a positive effect on tax planning. Company size has a negative effect on tax planning. Capital intensity has a positive effect on tax planning.
\end{abstract}

Keywords: profitability, leverage, company size, capital intensity, tax planning

\section{PENDAHULUAN}

Pajak merupakan beban bagi perusahaan yang dapat mengurangi laba bersih suatu perusahaan sehingga banyak perusahaan yang tidak senang jika membayar pajak. Perusahaan membayar pajak karena sifatnya memaksa, jika tidak membayar akan terkena sanksi yang dapat merugikan perusahaan. Bagi negara, pajak adalah salah satu sumber penerimaan penting yang akan digunakan untuk membiayai pengeluaran Negara, baik pengeluaran rutin maupun pengeluaran pembangunan (Suandy, 2016). Keberhasilan pembangunan nasional sangat didukung dengan adanya penerimaan pembayaran pajak. Namun, masih ada Wajib Pajak yang tidak berkontribusi dalam pembangunan nasional karena tidak melaksanakan kewajiban perpajakan. Untuk itu, perlu diterapkan adanya kebijakan berupa pengampunan pajak. Adanya kebijakan pengampunan pajak diharapkan kemungkinan untuk menyembunyikan kekayaan di luar wilayah Indonesia akan semakin berkurang. (Suharno, 2016). Pemerintah menetapkan Undang-Undang Nomor 11 Tahun 
2016 tentang Pengampunan Pajak (Tax Amnesty) sebagai upaya untuk membuat kebijakan baru yang mengatur pengampunan pajak. Pengampunan pajak adalah penghapusan pajak yang seharusnya terutang, tidak dikenai sanksi administrasi perpajakan dan sanksi pidana di bidang perpajakan, dengan cara mengungkap harta dan membayar uang tebusan sebagaimana diatur dalam Undang-Undang Pengampunan Pajak (Suharno, 2016).

Pada tahun 2017 target penerimaan pajak Indonesia adalah sebesar Rp1.450.939 miliar atau sebesar 84,65\% dari total penerimaan negara yang ditetapkan dalam Anggaran Pendapatan dan Belanja Perubahan (APBN-P) Tahun 2017. Jumlah penerimaan tersebut mengalami kenaikan sebesar Rp165.968,9 miliar atau mengalami pertumbuhan sebesar 12,9\% apabila dibandingkan dengan realisasi penerimaan perpajakan pada tahun 2016. Realisasi penerimaan perpajakan pada tahun 2016 sebesar Rp1.284.970,1 miliar tidak dapat memenuhi target yang ditetapkan Pemerintah pada APBN-P 2016 sebesar Rp1.539.166,2 miliar atau dengan kata lain hanya dapat memenuhi $83,48 \%$ dari target yang telah ditetapkan. Hal ini menunjukkan bahwa target penerimaan pajak masih belum memenuhi target (Kurniawati, 2017). Penerimaan pajak yang masih belum memenuhi target disebabkan karena banyaknya perusahaan yang melakukan praktik-praktik penghindaran pajak. Upaya meminimalkan beban pajak atau yang sering disebut sebagai perencanaan pajak (tax planning) dapat dilakukan dengan berbagai cara baik secara legal yang masih sesuai dengan aturan perpajakan maupun dilakukan secara ilegal. Meningkatnya kegiatan perencanaan pajak (tax planning) dapat merugikan negara karena praktik perencanaan pajak (tax planning) berakibat pada berkurangnya bahkan hilangnya uang pajak (Kurniawati, 2017).

Perencanaan pajak (tax planning) adalah proses pengendalian tindakan agar terhindar dari konsekuensi pengenaan pajak yang tidak dikehendaki (Handayani, 2018). Perencanaan pajak (tax planning) tidak sepenuhnya ilegal karena dalam meminimalkan pajak dapat juga dilakukan secara legal. Terdapat tiga tahapan atau langkah dalam meminimalkan pajak menurut Cahyono, et al., (2016) yaitu perusahaan berusaha untuk menghindari pajak baik secara legal maupun ilegal, mengurangi beban pajak seminimal mungkin baik secara legal maupun ilegal, namun apabila kedua langkah sebelumnya tidak dapat dilakukan maka wajib pajak akan membayar pajak tersebut. Inilah strategi dalam melakukan perencanaan pajak, sehingga tidak sedikit perusahaan yang melakukan perencanaan pajak dengan tujuan untuk meminimalisir pajak yang harus dibayar oleh perusahaan. Menurut Brotodihardjo (1993) dalam Halim, et al., (2017) teori daya pikul mengandung suatu kesimpulan bahwa dasar keadilan dalam pemungutan pajak adalah terletak pada jasa-jasa yang diberikan oleh Negara kepada warganya, yaitu perlindungan atas jiwa dan harta bendanya. Untuk memenuhi kepentingan tersebut dibutuhkan adanya biaya yang harus dipikul oleh warga dalam bentuk pajak. Hal yang menjadi pokok pangkal teori ini adalah asas pajak, yaitu tekanan pajak itu haruslah sama beratnya untuk setiap orang. Pajak harus dibayar sesuai dengan daya pikul seseorang dan untuk mengukur daya pikul dapat dilihat dari penghasilan, kekayaan dan besarnya pengeluaran seseorang dan memperhatikan besar kecilnya jumlah tanggungan keluarga. Terdapat beberapa faktor yang berpengaruh terhadap penghindaran pajak yaitu ukuran perusahaan, return on assets dan leverage, kemudian pada penelitian ini ditambahkan variabel capital intensity (Irianto, et al., 2017; Kasim dan Saad, 2019; Alfina, et al., 2018).

Profitabilitas merupakan rasio untuk mengukur efektivitas manajemen secara keseluruhan yang ditunjukkan olah besar kecilnya tingkat keuntungan yang diperoleh dalam hubungannya dengan penjual maupun investasi (Fahmi, 2014). Rasio ini menunjukkan tingkat efektivitas manajemen suatu perusahaan. Hal ini ditunjukkan oleh laba yang dihasilkan dari penjualan dan pendapatan investasi. Intinya bahwa penggunaan rasio ini menunjukkan efisiensi perusahaan. 
Leverage merupakan rasio yang menunjukkan bagaimana perusahaan mampu untuk mengelola hutangnya dalam rangka memperoleh keuntungan dan juga mampu untuk melunasi kembali hutangnya (Fahmi, 2014). Menurut Kasmir (2012) rasio leverage merupakan rasio yang digunakan untuk mengukur sejauh mana aktiva perusahaan dibiayai dengan utang. Artinya, berapa beban utang yang ditanggung perusahaan dibandingkan dengan aktivanya. Dalam arti luas dikatakan bahwa rasio leverage digunakan untuk mengukur kemampuan perusahaan untuk membayar seluruh kewajibannya baik jangka pendek maupun jangka panjang apabila perusahaan dibubarkan (dilikuidasi). Menurut Cahyono, et al. (2016) ukuran perusahaan merupakan skala atau nilai yang dapat mengklasifikasikan suatu perusahaan ke dalam kategori besar atau kecil yang dapat dilihat dari nilai total aktiva atau total asset perusahaan, nilai pasar saham, rata-rata penjualan yang dihasilkan perusahaan dan jumlah penjualan. Perusahaan-perusahaan yang berukuran besar akan lebih kompleks dalam transaksi mereka. Oleh karena itu, mendorong perusahaan mengambil celah untuk melakukan penghindaran pajak (Irianto, et al., 2017). Menurut Ardyansah dan Zulaikha (2014) capital intensity merupakan seberapa besar aktiva tetap dan persediaan yang dimiliki perusahaan. Rasio intensitas modal dapat menunjukkan efisiensi penggunaan aktiva untuk menghasilkan penjualan. Rasio intensitas modal juga sering dikaitkan dengan seberapa besar aktiva tetap dan saham yang dimiliki oleh perusahaan. Untuk mengukur komposisi aktiva terdapat tiga intensitas yaitu intensitas persediaan, intensitas modal, dan intensitas penelitian dan pengembangan (Indradi, 2018). Aset tetap yang besar akan membuat jumlah pajak yang dibayarkan perusahaan juga besar, sehingga akan mendorong perusahaan untuk mengambil tindakan terhadap penghindaran pajak (Irianto, et al., 2017).

Sampel yang digunakan dalam penelitian ini merupakan perusahaan Indeks Saham Syariah Indonesia (ISSI) yang terdaftar di Bursa Efek Indonesia. Indeks Saham Syariah Indonesia (ISSI) merupakan indikator dari kinerja pasar saham syariah Indonesia yang diluncurkan pada tanggal 12 Mei 2011. Keberadaan Indek Saham Syariah Indonesia (ISSI) melengkapi indeks syariah yang sudah ada sebelumnya yaitu Jakarta Islamic Index (JII). Konstituen Indeks Saham Syariah Indonesia (ISSI) adalah seluruh saham syariah yang tercatat di BEI dan masuk ke dalam Daftar Efek Syariah (DES) yang diterbitkan oleh OJK (www.idx.co.id). Konstituen Indeks Saham Syariah Indonesia (ISSI) direview setiap 6 bulan sekali (Mei dan November) dan dipublikasikan pada awal bulan berikutnya. Konstituen ISSI juga dilakukan penyesuaian apabila ada saham syariah yang baru tercatat atau dihapuskan dari Daftar Efek Syariah (DES). Saham-saham yang tergolong dalam Indeks Saham Syariah Indonesia (ISSI) merupakan saham yang telah memenuhi kriteria sebagai sebagai saham syariah dan dirangkum didalam Daftar Efek Syariah (DES) yang diterbitkan oleh Bapepam-LK (Suciningtias dan Khoiroh, 2015).

Perusahaan Indeks Saham Syariah Indonesia (ISSI) merupakan perusahaan yang dapat menerbitkan efek syariah dibatasi oleh kepemilikan utang berbasis bunga yang tidak boleh lebih dari 45\% dari total aset. Dengan demikian, perusahaan-perusahaan yang tergabung di Indeks Saham Syariah Indonesia (ISSI) hanya mempunyai sedikit insentif pajak yang berasal dari utang. Akan tetapi terdapat keunikan di dalam perusahaan ISSI yaitu masih banyaknya perusahaan ISSI yang terkait dengan kasus penghindaran pajak, seperti PT Toyota Astra Manufacturing yang masih merupakan anak perusahaan dari PT ASTRA. Direktorat Jenderal Pajak menuding PT Toyota Motor Manufacturing Indonesia menghindari pembayaran pajak senilai Rp 1,2 triliun dengan transfer pricing (Andawiyah, et al., 2019). Berdasarkan latar belakang yang telah diuraikan di atas maka judul dalam penelitian ini adalah "Faktor-Faktor yang Mempengaruhi Perencanaan Pajak Pada Perusahaan-perusahaan dalam Indeks Saham Syariah Indonesia (ISSI) yang Terdaftar di Bursa Efek Indonesia". 


\section{TINJAUAN PUSTAKA \\ Tax Planning}

Perencanaan pajak disebut juga sebagai tax planning, yaitu proses pengendalian tindakan agar terhindar dari konsekuensi pengenaan pajak yang tidak dikehendaki (Handayani, 2018). Menurut Pohan (2016) tax planning adalah proses mengorganisasi usaha wajib pajak orang pribadi maupun badan usaha sedemikian rupa dengan memanfaatkan berbagai celah kemungkinan yang dapat ditempuh oleh perusahaan dalam koridor ketentuan pengaturan perpajakan (loopholes), agar perusahaan dapat membayar pajak dalam jumlah minimum. Berdasarkan beberapa definisi di atas, maka tax planning dapat didefinisikan sebagai suatu alat dan suatu tahap awal dari manajemen perpajakan (tax management) yang berfungsi untuk menampung aspirasi yang berkembang dari sifat dasar manusia itu. Tujuan utama tax planning adalah mencari berbagai celah yang dapat ditempuh dalam korior peraturan perpajakan (loopholes) agar perusahaan dapat membayar pajak dalam jumlah minimal. Dalam tax planning ada tiga macam cara yang dapat dilakukan oleh wajib pajak untuk menekan jumlah beban pajaknya, yang terdiri dari (Pohan, 2016)Tax Avoidance (Penghindaran Pajak), Tax Evasion (Penyelundupan Pajak) dan Tax Saving (Penghematan Pajak).

\section{Profitabilitas}

Profitabilitas merupakan rasio untuk mengukur efektivitas manajemen secara keseluruhan yang ditunjukkan olah besar kecilnya tingkat keuntungan yang diperoleh dalam hubungannya dengan penjual maupun investasi (Fahmi, 2014). Pada penelitian ini profitabilitas diwakilkan dengan Return On Assets (ROA). Return On Assets (ROA) merupakan rasio untuk melihat sejauh mana investasi yang telah ditanamkan mampu memberikan pengembalian keuntungan sesuai dengan yang diharapkan (Fahmi, 2014).

\section{Leverage}

Leverage merupakan rasio yang menunjukkan bagaimana perusahaan mampu untuk mengelola hutangnya dalam rangka memperoleh keuntungan dan juga mampu untuk melunasi kembali hutangnya (Fahmi, 2014). Menurut Hanafi dan Halim (2018) leverage merupakan rasio yang mengukur sejauh mana kemampuan perusahaan memenuhi kewajiban jangka panjangnya. Pada penelitian ini leverage diwakilkan dengan Debt to Equity Ratio (DER). Debt to Equity Ratio merupakan ukuran yang dipakai dalam menganalisis laporan keuangan untuk memperlihatkan besarnya jaminan yang tersedia untuk kreditur. Semakin tinggi rasio ini berarti modal sendiri yang digunakan semakin sedikit dibandingkan dengan hutangnya atau kewajibannya (Fahmi, 2014).

\section{Ukuran Perusahaan}

Menurut Cahyono, et al. (2016) ukuran perusahaan merupakan skala atau nilai yang dapat mengklasifikasikan suatu perusahaan ke dalam kategori besar atau kecil yang dapat dilihat dari nilai total aktiva atau total asset perusahaan, nilai pasar saham, rata-rata penjualan yang dihasilkan perusahaan dan jumlah penjualan. Menurut Ardyansah dan Zulaikha (2014) ukuran perusahaan atau size dapat diartikan sebagai suatu skala dimana persahaan dapat diklasifikasikan besar kecilnya berdasarkan aset yang dimiliki. Ukuran perusahaan dapat menentukan persepsi investor terhadap suatu perusahaan. Semakin besar ukuran perusahaan dapat memberikan asumsi bahwa perusahaan tersebut dikenal oleh masyarakat luas. Investor cenderung memberikan perhatian yang khusus terhadap perusahaan besar karena dianggap memiliki 
kondisi yang stabil dan lebih mudah dalam hal sumber pendanaan yang bersifat internal maupun eksternal.

\section{Capital Intensity}

Menurut Ardyansah dan Zulaikha (2014) capital intensity merupakan seberapa besar aktiva tetap dan persediaan yang dimiliki perusahaan. Capital intensity atau rasio intensitas modal adalah aktivitas investasi perusahaan yang dikaitkan dengan investasi aset tetap dan persediaan (Indradi, 2018). Capital intensity dapat menunjukkan apakah perusahaan sudah efisien atau belum dalam penggunaan aktiva untuk menghasilkan penjualan. Capital intensity juga dapat didefinisikan dengan bagaimana perusahaan berkorban dalam mengeluarkan data untuk segala aktivitas operasi perusahaan dan penadaan pada aktivanya dengan tujuan untuk memperoleh keuntungan perusahaan (Indradi, 2018).

\section{MODEL PENELITIAN}

\begin{tabular}{|c|c|c|}
\hline Profitabilitas & $\mathrm{H} 1$ \\
\hline Leverage & $\mathrm{H} 2$ \\
\hline Ukuran Perusahaan & $\mathrm{H3 \quad H4}$ & $\begin{array}{c}\text { Perencanaan } \\
\text { Pajak }\end{array}$ \\
\hline Canital Intensitv & Gambar 1. Model Penelitian \\
\hline
\end{tabular}

\section{HIPOTESIS}

H1 : Profitabilitas berpengaruh negatif terhadap perencanaan pajak.

$\mathrm{H} 2$ : Leverage berpengaruh positif terhadap perencanaan pajak.

H3 : Ukuran perusahaan berpengaruh negatif terhadap perencanaan pajak.

$\mathrm{H} 4$ : Capital intensity berpengaruh positif terhadap perencanaan pajak.

\section{METODE PENELITIAN}

Jenis penelitian ini merupakan penelitian kuantitatif. Penelitian kuantitatif adalah jenis penelitian yang menghasilkan penemuan-penemuan yang dapat dicapai dengan menggunakan prosedurprosedur statistik atau cara-cara lain dari kualifikasi atau pengukuran (Sujarweni, 2018). Populasi dalam penelitian ini populasinya adalah perusahaan Indeks Saham Syariah Indonesia (ISSI) yang terdaftar di Bursa Efek Indonesia tahun 2018 yang berjumlah 400 perusahaan.Teknik pengambilan sampel dalam penelitian ini menggunakan teknik purposive sampling, yaitu teknik penentuan sampel dengan pertimbangan atau keriteria-kriteria tertentu (Sujarweni, 2018). Sumber data utama yang digunakan dalam penelitian ini merupakan data sekunder yang diperoleh dari laporan keuangan perusahaan Indeks Saham Syariah Indonesia (ISSI) yang terdaftar di Bursa Efek Indonesia tahun 2018. Teknik pengumpulan data dalam penelitian ini menggunakan metode dokumenter yang dilakukan dengan menganalisis isi dan dokumendokumen yang mendukung penelitian yang sesuai dengan data penelitian. Teknik analisis yang digunakan menggunakan analisis regresi linier berganda 


\section{HASIL PENELITIAN}

\section{Pengujian Asumsi Klasik}

Uji Normalitas

Uji normalitas adalah uji yang digunakan untuk mengetahui data pada penelitian berdistribusi normal atau tidak. Berdasarkan hasil perhitungan pada uji normalitas dengan menggunakan uji Kolmogorov-Smirnov diketahui bahwa nilai signfikansinya sebesar 0,411. Nilai signifikansinya ini lebih besar dari 0,05 sehingga pada penelitian dapat dinyatakan bahwa data berdistribusi normal.

Tabel 1. Hasil Uji Normalitas

\begin{tabular}{clc}
\hline No & \multicolumn{1}{c}{ Keterangan } & Nilai \\
\hline 1. & Kolmogorov-Smirnov Z & 0,887 \\
2. & Asymp. Sig. (2-tailed) & 0,441 \\
\hline
\end{tabular}

Sumber: Data diolah, (2020)

Uji Multikolinieritas

Uji multikolinieritas dalam penelitian ini menggunakan nilai TOL dan VIF. Berdasarkan Tabel 2 dapat diketahui bahwa nilai TOL masing-masing variabel lebih besar dari 0,1 dan nilai VIF lebih kecil dari 10. Dengan begitu dapat diketahui bahwa variabel profitabilitas, leverage, ukuran perusahaan dan capital intensity tidak terdapat gejala multikolinieritas.

Tabel 2. Hasil Uji Multikolinieritas

\begin{tabular}{clcc}
\hline No & \multicolumn{1}{c}{ Variabel } & Nilai TOL & Nilai VIF \\
\hline 1. & Profitabilitas & 0,916 & 1,092 \\
2. & Leverage & 0,856 & 1,168 \\
3. & Ukuran Perusahaan & 0,910 & 1,099 \\
4. & Capital Intensity & 0,936 & 1,068 \\
\hline
\end{tabular}

Sumber: data diolah, (2020)

Uji Heteroskedastisitas

Uji heteroskedastisitas yang digunakan pada penelitian ini menggunakan uji glejser. Tabel 3 menunjukkan bahwa nilai signifikansi masing-masing variabel lebih besar dari 0,05 sehingga variabel pada penelitian ini dapat dinyatakan tidak terjadi gejala heteroskedastisitas.

Tabel 3. Hasil Uji Heteroskedastisitas

\begin{tabular}{clc}
\hline No & \multicolumn{1}{c}{ Variabel } & Nilai Signifikansi \\
\hline 1. & Profitabilitas & 0,061 \\
2. & Leverage & 0,374 \\
3. & Ukuran Perusahaan & 0,949 \\
4. & Capital Intensity & 0,112 \\
\hline
\end{tabular}


Sumber: data diolah, (2020)

\section{Hasil Uji Analisis Regresi Linier Berganda}

Penelitian ini menggunakan analisis regresi linier berganda yang bertujuan untuk mengetahui pengaruh variabel bebas terhadap variabel terikatnya. Adapun variabel bebas pada penelitian ini yaitu profitabilitas, leverage, ukuran perusahan, dan capital intensity. Sedangkan variabel terikat yang digunakan pada penelitian ini yaitu perencanaan pajak.

Tabel 4. Hasil Uji Analisis Regresi Linier Berganda

\begin{tabular}{lcccc}
\hline \multicolumn{1}{c}{ Variabel } & Koefisien & t hitung & Nilai Sig & Keterangan \\
\hline Profitabilitas & $-0,220$ & $-1,192$ & 0,235 & Ditolak \\
Leverage & 0,024 & 2,351 & 0,020 & Diterima \\
Ukuran Perusahaan & $-0,017$ & $-3,206$ & 0,002 & Diterima \\
Capital Intensity & 0,211 & 5,054 & 0,000 & Diterima \\
Konstanta & 0,655 & & & \\
\hline
\end{tabular}

Sumber: data diolah, (2020)

\section{Pengujian Koefisien Regresi Secara Simultan (Uji F)}

Nilai $\mathrm{F}$ hitung menunjukkan bahwa nilai signifikansi sebesar 0,000 kurang dari 0,05 sehingga peneliti menyimpulkan dalam penelitian ini bahwa terdapat pengaruh secara simultan antara profitabilitas, leverage, ukuran perusahaan dan capital intensity terhadap perencanaan pajak sehingga model pada persamaan regresi dinyatakan fit yang ditunjukkan pada Tabel 5.

Tabel 5. Hasil Uji F

\begin{tabular}{rcrrrrr}
\hline \multicolumn{1}{l}{ Model } & $\begin{array}{c}\text { Sum of } \\
\text { Squares }\end{array}$ & df & $\begin{array}{c}\text { Mean } \\
\text { Square }\end{array}$ & F & Sig. \\
\hline \multirow{3}{*}{1} & Regression & 0,689 & 4 & 0,172 & 10,921 & $0,000^{\text {a }}$ \\
& Residual & 3,106 & 197 & 0,016 & & \\
& Total & 3,795 & 201 & & & \\
\hline
\end{tabular}

Sumber: data diolah, (2020)

Adjusted $R^{2}$ (Model Fit/ Uji Kesesuaian Model)

Pada penelitian ini menggunakan Adjusted $R^{2}$ untuk menguji ketepatan model. Tabel 6 menunjukkan bahwa perencanaan pajak sebesar 0,165 atau 16,5\%. Artinya profitabilitas, leverage, ukuran perusahaan dan capital intensity mempengaruhi perencanaan pajak sebesar $31,9 \%$ sedangkan sisanya sebesar sebesar $83,5 \%$ dipengaruhi oleh variabel lain yang tidak diteliti oleh peneliti.

Tabel 6. Hasil Uji Adjusted $R^{2}$ 


\begin{tabular}{ccccc}
\hline Model & $\mathrm{R}$ & R Square & Adjusted R Square & $\begin{array}{c}\text { Std. Error of the } \\
\text { Estimate }\end{array}$ \\
\hline 1 & $0,426^{\mathrm{a}}$ & 0,182 & 0,165 & 0,1255732 \\
\hline
\end{tabular}

Sumber: data diolah, (2020)

\section{PEMBAHASAN}

\section{Pengaruh profitabilitas terhadap perencanaan pajak}

Berdasarkan hasil analisis regresi linier berganda yang telah dilakukan peneliti di atas, diketahui bahwa profitabilitas tidak berpengaruh terhadap perencanaan pajak. Hal tersebut karena nilai thitung $-1,192<\mathrm{t}$ tabel 1,97202 dengan nilai signifikansi 0,235 > 0,05 yang dapat diartikan bahwa profitabilitas tidak berpengaruh terhadap perencanaan pajak. Profitabilitas merupakan rasio untuk mengukur efektivitas manajemen secara keseluruhan yang ditunjukkan olah besar kecilnya tingkat keuntungan yang diperoleh dalam hubungannya dengan penjual maupun investasi (Fahmi, 2014). Dalam penelitian ini rasio profitabilitas yang digunakan adalah return on assets (ROA). Berdasarkan perhitungan, penelitian ini menujukkan bahwa profitabilitas tidak berpengaruh terhadap perencanaan pajak. Perusahaan yang memiliki tingkat laba tinggi maka memiliki beban pajak yang rendah. Hal ini dapat dipengaruhi oleh pendapatan yang tidak boleh dianggap sebagai objek pajak tetapi dimasukkan sebagai objek pajak, contohnya adalah dividen pendapatan dengan tingkat kepemilikan $25 \%$ atau lebih dan pendapatan operasional lainnya (Prasetyo, et al., 2018).

Hasil penelitian ini didukung oleh Alfina, et al. (2018) yang memperjelas bahwa meningkatnya tingkat kesadaran masyarakat dalam kewajiban membayar pajak sehingga nilai ROA yang tinggi menunjukkan bahwa perusahaan telah memanfaatkan asetnya secara efektif dan efisien sehingga perusahaan dapat membayar beban perusahaannya termasuk beban pajak, maka perusahaan yang mempunyai nilai ROA yang tinggi akan lebih baik jika membayar beban pajak daripada harus melakukan tindakan penggelapan pajak. Hasil penelitian ini sejalan dengan penelitian yang dilakukan oleh Ardyansah dan Zulaikha (2014) yang juga menyatakan bahwaprofitabilitas tidak berpengaruh terhadap effective tax rate. Didukung oleh penelitian yang dilakukan Anouar (2017) yang juga menyatakan bahwa profitabilitas tidak berpengaruh terhadap tax avoidance.

\section{Pengaruh leverage terhadap perencanaan pajak}

Berdasarkan hasil analisis regresi linier berganda yang telah dilakukan penelitian di atas, diketahui bahwa leverage berpengaruh positif terhadap perencanaan pajak. Hal tersebut karena nilai t hitung 2,351 > t tabel 1,97202 dengan nilai signifikansi 0,020 $<0,05$ yang dapat diartikan 
bahwa leverage berpengaruh positif terhadap perencanaan pajak. Leverage merupakan rasio yang menunjukkan bagaimana perusahaan mampu untuk mengelola hutangnya dalam rangka memperoleh keuntungan dan juga mampu untuk melunasi kembali hutangnya (Fahmi, 2014). Dalam penelitian ini rasio leverage yang digunakan adalah Debt to Equity Ratio (DER). Berdasarkan perhitungan, hasil penelitian ini menunjukkan bahwa leverage berpengaruh positif terhadap perencanaan pajak. Artinya semakin tinggi rasio leverage maka menunjukkan semakin tinggu jumlah pendanaan perusahaan yang berasal dari pihak ketiga. Selanjutnya pihak ketiga tersebut akan melakukan pengawasan yang ketat terhadap manajer perusahaan. Semakin tingginya pengawasan yang dilakukan oleh kreditur maka dapat membuat manajer menjadi lebih berhati-hati dalam membuat keputusan pajak (Wijayanti dan Merkusiwati, 2017). Hasil penelitian ini sejalan dengan penelitian yang dilakukan oleh Alfina, et al., (2018) dan Annisa (2017) yang menyatakan bahwa leverage berpengaruh positif terhadap tax avoidance. Didukung oleh penelitian yang dilakukan oleh Puspita dan Febrianti (2017) yang juga menyatakan bahwa leverage berpengaruh positif terhadap penghindaran pajak.

\section{Pengaruh ukuran perusahaan terhadap perencanaan pajak}

Berdasarkan hasil analisis regresi linier berganda yang telah dilakukan penelitian diatas, diketahui bahwa ukuran perusahaan berpengaruh negatif terhadap perencanaan pajak. Hal tersebut karena nilai t hitung -3,206 <-t tabel -1,97202 dengan nilai signifikansi 0,002<0,05 yang dapat diartikan bahwa ukuran perusahaan berpengaruh negatif terhadap perencanaan pajak. Menurut Cahyono, et al. (2016) ukuran perusahaan merupakan skala atau nilai yang dapat mengklasifikasikan suatu perusahaan ke dalam kategori besar atau kecil yang dapat dilihat dari nilai total aktiva atau total asset perusahaan, nilai pasar saham, rata-rata penjualan yang dihasilkan perusahaan dan jumlah penjualan. Berdasarkan hasil perhitungan, penelitian ini menujukkan bahwa ukuran perusahaan berpengaruh negatif terhadap perencanaan pajak. Menurut Rodriguez dan Arias (2012) dalam Ardyansah dan Zulaikha (2014), perusahaan besar cenderung memiliki ruang lebih besar untuk perencanaan pajak yang baik dan mengadopsi praktek akuntansi yang efektif untuk menurunkan Effective Tax Rate (ETR) perusahaan. Aset yang dimiliki suatu perusahaan berhubungan dengan besar kecilnya perusahaan. Perusahaan yang besar cenderung mempunyai aset yang besar. Aset akan mengalami penyusutan setiap tahunnya yang dapat mengurangi laba bersih perusahaan, sehingga menurunkan beban pajak yang dibayarkan. Hal ini menunjukkan bahwa, semakin besar perusahaan maka akan semakin rendah Effective Tax Rate (ETR) yang dimilikinya. Hasil penelitian ini sejalan dengan Irianto, et al., (2017) menyatakan bahwa ukuran perusahaan berpengaruh negatif terhadap tax avoidance. Penelitian ini juga didukung oleh Alfina, et al., (2018) juga menyatakan bahwa ukuran perusahaan berpengaruh negatif erhadap tax avoidance. Penelitian yang dilakukan oleh Ardyansyah dan 
Zulaikha (2014) juga menyatakan bahwa ukuran perusahaan berpengaruh negatif terhadap Effective Tax Rate (ETR).

\section{Pengaruh capital intensity terhadap perencanaan pajak}

Berdasarkan hasil analisis regresi linier berganda yang telah dilakukan penelitian diatas, diketahui bahwa capital intensity berpengaruh positif terhadap perencanaan pajak. Hal tersebut karena ditunjukkan dari nilai t hitung 5,054 > t tabel 1,97202 dengan nilai signifikansi 0,000< 0,05 yang dapat diartikan bahwa capital intensity berpengaruh positif terhadap perencanaan pajak. Menurut Ardyansah dan Zulaikha (2014) capital intensity merupakan seberapa besar aktiva tetap dan persediaan yang dimiliki perusahaan. Berdasarkan perhitungan, hasil penelitian ini menujukkan bahwa capital intensity berpengaruh positif terhadap perencanaan pajak. Perusahaan yang memiliki aktiva tetap yang tinggi akan memiliki pajak yang lebih rendah dibandingkan perusahaan yang mempunyai aktiva tetap yang rendah. Semakin besar aktiva tetap maka perusahaan akan cenderung untuk melakukan perencanaan pajak (Ardyansah dan Zulaikha, 2014). Hasil penelitian ini sejalan dengan penelitian yang dilakukan oleh Kasim dan Saad (2019) yang menyatakan bahwa capital intensity berpengaruh positif terhadap tax avoidance. Sejalan dengan penelitian yang dilakukan oleh Dharma dan Noviari (2017) juga menyatakan bahwa capital intensity berpengaruh positif terhadap tax avoidance.

\section{KESIMPULAN}

\section{Kesimpulan}

Berdasarkan hasil penelitian yang telah dilakukan oleh peneliti di atas, maka peneliti dapat mengambil kesimpulan sebagai berikut: (1) Profitabilitas tidak berpengaruh terhadap perencanaan pajak pada perusahaan Indeks Saham Syariah Indonesia (ISSI) di Bursa Efek Indonesia tahun 2018. (2) Leverage berpengaruh positif terhadap perencanaan pajak pada perusahaan Indeks Saham Syariah Indonesia (ISSI) di Bursa Efek Indonesia tahun 2018. (3) Ukuran perusahaan berpengaruh negatif terhadap perencanaan pajak pada perusahaan Indeks Saham Syariah Indonesia (ISSI) di Bursa Efek Indonesia tahun 2018. (4) Capital intensity berpengaruh positif terhadap perencanaan pajak pada perusahaan Indeks Saham Syariah Indonesia (ISSI) di Bursa Efek Indonesia tahun 2018.

\section{Implikasi}

Berdasarkan hasil penelitian yang telah dilakukan oleh peneliti maka implikasi yang dapat diberikan adalah sebagai berikut : (1) Perusahaan harus lebih berhati-hati memperhatikan dalam melakukan perencanaan Perusahaan harus lebih berhati-hati memperhatikan dalam melakukan perencanaan pajak (tax planning) agar perusahaan tidak salah dalam pengambilan keputusan dalam perpajakan yang dapat menyebabkan risiko melanggar peraturan perpajakan. (2) Apabila 
perusahaan hendak melakukan perencaan pajak dengan mengurangi beban pajak, sebaiknya perusahaan melakukan pemilihan pendanaan yang dapat mempertimbangkan keuntungan dalam perpajakan. (3) Bagi fikus atau pemerintah dalam hal ini adalah Direktorat Jenderal Pajak (DJP) sebaiknya lebih meningkatkan monitoring dan pengawasan terhadap kewajiban perpajakan perusahaan dengan lebih meningkatkan pemahaman metode pencatatan yang dipilih oleh perusahaan.

Secara teoritis hasil penelitian ini membuktikan bahwa Profitabilitas tidak berpengaruh terhadap perencanaan pajak. Leverage berpengaruh negatif terhadap perencanaan pajak, serta ukuran perusahaan dan capital intensity berpengaruh positif terhadap perencanaan pajak. Hasil penelitian ini juga dapat di jadikan reverensi untuk penelitian selanjutnya.

\section{Keterbatasan Penelitian}

Peneliti menyadari bahwa penelitian yang dilakukan oleh peneliti ini jauh dari kata sempurna. Di dalam melaksanakan penelitian ini, tentu saja peneliti mengalami keterbatasan yang harus dilewati. Adapun keterbatasan dalam penelitian ini adalah hanya setengah dari perusahaan Indeks Saham Syariah Indonesia (ISSI) yang lolos sebagai sampel penelitian dikarenakan tidak memenuhi syarat dalam penelitian ini.

\section{DAFTAR PUSTAKA}

Agus, Prasetyo, Endang Masitoh, Anita Wijayanti. (2018). The Influence of Good Corporate Governance, Capital Intensity Ratio, and Profitability to Effective Tax Rate (Empirical Study on Manufacturing Companies Basic Industry Sectors and Chemicals Listed In Indonesia Stock Exchange Year 20112015). The 2nd International Conference on Technology, Education, and Social Science 2018 (The 2nd ICTESS 2018).

Andawiyah, A., Ahmad Subeki, Arista Hakiki. (2019). Pengaruh Thin Capitalization Terhadap Penghindaran Pajak Perusahaan Index Saham Syariah Indonesia. Jurnal Penelitian dan Pengembangan Akuntansi, Vol. 13 No. 1 Januari 2019.

Alfina, I. T., Nurlaela, S., \& Wijayanti, A. (2018). The Influence of Profitability , Leverage , Independent Commissioner, and Company Size to Tax Avoidance. The 2nd International Conference on Technology, Education, and Social Science 2018, 2018(10), 102-106.

Annisa. (2017). Pengaruh Return on Asset, Leverage, Ukuran Perusahaan dan Koneksi Politik Terhadap Penghindaran Pajak (Studi Empiris pada Perusahaan Manufaktur yang Terdaftar di BEI Periode Tahun 2012-2015) , JOM Fekon, Vol. 4 No.1 (Februari) 2017.

Anouar, D. (2017). The Determinants of Tax Avoidance within Corporate Groups: Evidence from Moroccan Groups. International Journal of Economics, Finance and Management Sciences, 5(1), 57. https://doi.org/10.11648/j.ijefm.20170501.15

Ardyansah, D., dan Zulaikha. (2014). Pengaruh Size, Leverage, Profitability, CapitalIntensity Ratio dan Komisaris Independen Terhadap Effective Tax Rate (ETR). Diponegoro Journal of Accounting. Volume 3, Nomor 2, Tahun 2014, Halaman 1-9. ISSN (Online): 2337-3806.

Cahyono, D.D., Andini, R., Raharjo,K. (2016). Pengaruh Komite Audit, Kepemilikan Institusional, Dewan Komisaris, Ukuran Perusahaan (Size), Leverage (DER) dan Profitabilitas (ROA) Terhadap Tindakan 
Penghindaran Pajak (Tax Avoidance) Pada Perusahaan Perbankan yang Listing BEI Periode Tahun 2011 - 2013. Journal Of Accounting, Volume 2 No.2 Maret 2016.

Dharma, N.B.S., Noviari, N. (2017). Pengaruh Corporate Social Responsibilty dan Capital Intensity Terhadap Tax Avoidance. E-Jurnal Akuntansi Universitas Udayana Vol.18.1. Januari (2018): 529-556. ISSN: 2303-8556.

Fahmi, Irham. (2014). Pengantar Manajemen Keuangan, Teori dan Soal Jawab. Alfabeta, Bandung.

Halim, Abdul, Icuk Rangga Bawono, Amin Dara. (2017). Perpajakan: Konsep, Aplikasi, Contoh, dan Studi Kasus Edisi 2. Salemba Empat: Jakarta.

Hanafi, Mamduh M dan Halim, Abdul. (2018). Analisis Laporan Keuangan. UPP STIM YKPN: Yogyakarta.

Handayani, R. (2018). Pengaruh Return on Assets (ROA), Leverage dan Ukuran Perusahaan Terhadap Tax Avoidance Pada Perusahaan Perbankan yang Listing di BEI Periode Tahun 2012-2015. Jurnal Akuntansi Maranatha, 10(1), 72-84. https://doi.org/10.28932/jam.v10i1.930

Irianto, D. S., Sudibyo, A.Y., Wafirli, A. (2017). The Influence of Profitability, Leverage, Firm Size and Capital Intensity Towards Tax Avoidance. Internasional Jurnal Akuntansi dan Perpajakan. Vol. 5, No. 2.

Kasim, F. M., \& Saad, N. (2019). Determinants of Corporate Tax Avoidance Strategies among Multinational Corporations in Malaysia. International Journal of Public Policy and Administration Research, 6(2), 7481. https://doi.org/10.18488/journal.74.2019.62.74.81

Kasmir. (2012). Analisis Laporan Keuangan. PT. Raja Grafindo Persada. Jakarta.

Pohan, Chairil Anwar. (2016). Manajemen Perpajakan, Strategi Perencanaan Pajak dan Bisnis. PT. Gramedia Pustaka: Jakarta.

Puspita, D., dan Febrianti,M. (2017). Faktor-faktor yang mempengaruhi Penghindaran Pajak pada Perusahaan Manufaktur di Bursa Efek Indonesia. Jurnal Bisnis dan Akuntansi, Vol 19, No. 1, Juni 2017, Hal. 38-46. https://doi.org/10.34208/jba.v19i1.63.

Rodriguez dan Arias. (2012). Do Bussines Characteristics Determine An Effective Tax Rate. The Chinese Economy, $60-83$.

Suandy, Erly. (2016). Perencanaan Pajak Edisi 6. Salemba Empat: Jakarta.

Suharno. (2018). Panduan Praktis Amnesti Pajak Indonesia. Penerbit Buku Kompas: Jakarta.

Sujarweni, V. Wiratna. (2018). Metodologi Penelitian Bisnis dan Ekonomi Pendekatan Kuantitatif. Pustaka Baru Press:Yogyakarta.

Undang-Undang Republik Indonesia Nomor 11 Tahun 2016 tentang Pengampunan Pajak.

Wijayanti, Y.C., Merkusiwati, N.K.L.A. (2017). Pengaruh Proporsi Komisaris Independen, Kepemilikan Institusional, Leverage, dan Ukuran Perusahaan Pada Penghindaran Pajak. E-Jurnal Akuntansi Universitas Udayana Vol.20.1. Juli (2017): 699-728, ISSN: 2302-8556. 